\title{
Decarboxylative and dehydrative coupling of dienoic acids and pentadienyl alcohols to form 1,3,6,8-tetraenes
}

\author{
Ghina'a I. Abu Deiab ${ }^{\ddagger 1}$, Mohammed H. Al-Huniti ${ }^{\ddagger 1}$, I. F. Dempsey Hyatt ${ }^{1, \S}$, \\ Emma E. Nagy ${ }^{1}$, Kristen E. Gettys ${ }^{1}$, Sommayah S. Sayed ${ }^{1}$, Christine M. Joliat ${ }^{1}$, \\ Paige E. Daniel ${ }^{1}$, Rupa M. Vummalaneni ${ }^{1}$, Andrew T. Morehead $\mathrm{Jr}^{2}$, Andrew L. Sargent ${ }^{2}$ \\ and Mitchell P. Croatt ${ }^{* 1}$
}

\author{
Full Research Paper \\ Address: \\ ${ }^{1}$ Department of Chemistry and Biochemistry, University of North \\ Carolina at Greensboro, Greensboro, NC 27402, USA and \\ ${ }^{2}$ Department of Chemistry, East Carolina University, Greenville, NC \\ 27858, USA \\ Email: \\ Mitchell P. Croatt ${ }^{*}$ - mpcroatt@uncg.edu \\ * Corresponding author $\ddagger$ Equal contributors \\ $\S$ Current address: Department of Chemistry, Adelphi University, \\ Garden City, NY 11530, USA \\ Keywords: \\ decarboxylation; diene; dienoate; palladium; pentadienyl; tetraene \\ Beilstein J. Org. Chem. 2017, 13, 384-392. \\ doi:10.3762/bjoc. 13.41 \\ Received: 17 November 2016 \\ Accepted: 03 February 2017 \\ Published: 28 February 2017 \\ Associate Editor: B. Stoltz \\ (ㄷ) 2017 Deiab et al.; licensee Beilstein-Institut. \\ License and terms: see end of document.
}

Open Access

\begin{abstract}
Dienoic acids and pentadienyl alcohols are coupled in a decarboxylative and dehydrative manner at ambient temperature using $\operatorname{Pd}(0)$ catalysis to generate 1,3,6,8-tetraenes. Contrary to related decarboxylative coupling reactions, an anion-stabilizing group is not required adjacent to the carboxyl group. Of mechanistic importance, it appears that both the diene of the acid and the diene of the alcohol are required for this reaction. To further understand this reaction, substitutions at every unique position of both coupling partners was examined and two potential mechanisms are presented.
\end{abstract}

\section{Introduction}

The construction of $\mathrm{sp}^{2}-\mathrm{sp}^{3}$ carbon-carbon bonds remains a difficult and important problem in organic synthesis. Cross-coupling reactions provide avenues to these otherwise difficult reactions, but often require prefunctionalization of the coupling partners [1-9]. However, recent $\mathrm{C}-\mathrm{H}$ activation research has enabled the use of further simplified starting materials [10-18].
Another approach to the formation of $\mathrm{C}-\mathrm{C}$ bonds is through decarboxylative coupling reactions (Scheme 1). This can be arrived in a one-component fashion via the removal of $\mathrm{CO}_{2}$ from an ester or in a two-component manner by removal of $\mathrm{CO}_{2}$ from a carboxylic acid and coupling this to a substrate with a benzylic or allylic leaving group [19,20]. 


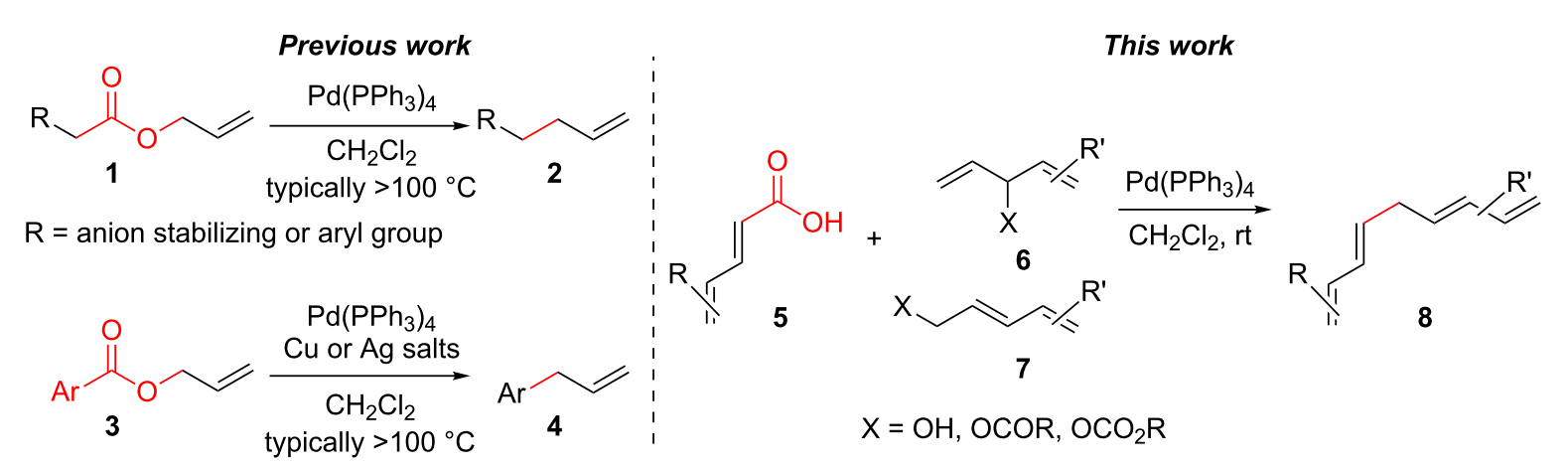

Scheme 1: Prior and current decarboxylative couplings.

Typical Pd(0)-catalyzed decarboxylative coupling reactions utilize an allylic or benzylic ester with either an anion-stabilizing group adjacent to the carboxyl group (i.e., carbonyl [19,21,22], nitrile [23-25], nitro [26,27], or alkyne [21,28-32], Scheme 1), or use an aryl carboxylate [33,34] which typically requires the assistance of silver or copper(I) salts for the decarboxylative step. It is rare to use a pentadienyl electrophile [35], or to have a diene or simple alkene adjacent to the carboxyl group [20,36-39]. Despite the absence of this type of reactivity, the decarboxylative coupling of a pentadienyl dienoate (9; Scheme 2) was desirable enough for our group's synthesis of clinprost that we attempted the reaction [40,41]. Fortunately, this coupling reaction was successfully employed in our reported nine-step synthesis of clinprost [41]. A structurally related compound (11) reacted similarly, however, the sorbate derivative (13) was low yielding with the majority of the material only rearranging to the linear ester. In all three of these cases, we never observed the more stable, fully conjugated tetraene. "Skipped diene" motifs are found in various natural products and there are few methods available to prepare these dienes [42-52]. Skipped tetraene systems have even fewer methods for their synthesis [53-55], which makes the method described herein even more valuable.

It was determined that modifying the dienoate motif yielded only the rearranged product under the reaction conditions, in-

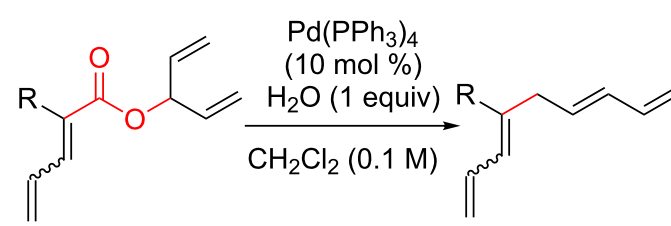

$$
9 \mathrm{R}=
$$

$\left(\mathrm{CH}_{2}\right)_{4} \mathrm{CO}_{2} \mathrm{Me}$<smiles>C=CC=C(CC)C(=O)OC(C=C)C=C</smiles>

11 $\mathrm{Pd}\left(\mathrm{PPh}_{3}\right)_{4}$ $(10 \mathrm{~mol} \%)$ $76 \%(\sim 1: 1 E / Z)$

$\mathrm{CDCl}_{3}(0.1 \mathrm{M})$

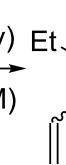

12
$10 \mathrm{R}=\left(\mathrm{CH}_{2}\right)_{4} \mathrm{CO}_{2} \mathrm{Me}$<smiles>C=CC=C(CC)CC=CC=II</smiles>
$62-80 \%(\sim 1: 1 E / Z)$<smiles>C=CC(C=C)OC(=O)/C=C/C=C/C</smiles><smiles>C=CCOC(=O)C(CC=C)CC(=O)OC</smiles>

16<smiles>C=CCOC(=O)C(=CC=CC)C(=O)OCC=CC=CC</smiles>

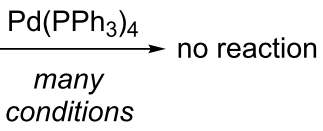

absence of dienoate AND pentadiene = no decarboxylation observed 
cluding the dihydro (14), cinnamate (15), benzoate (16), and acrylate (17) analogues (Scheme 2). Moreover, allylic dienoates 18 and 19 gave no reaction with $\operatorname{Pd}(0)$ catalysis. These results led us to the determination that there was a unique reactivity imbued to the molecule by having both the dienoate and pentadienyl moieties. Herein, are presented more details for this reaction, including the substrate scope for the intermolecular case.

\section{Results and Discussion}

In addition to determining the requisite nature of both the pentadienyl and dienoate groups, it was found that trace amounts of water were required for decarboxylative coupling (Table 1). For example, careful exclusion of water from reagents and solvent and performing the reaction in the glovebox led to formation of rearranged product and no decarboxylative coupling reaction (22, Table 1, entry 1). Less than 1 equivalent of water allowed for a slow reaction and incomplete conversion, 1-2 equivalents was optimal with yields around $70 \%$ and more water was not beneficial (Table 1, entries 2-8). The use of equimolar amounts of methanol and water as a proton source allowed for decarboxylation to take place but with a low yield (Table 1, entry 9) and the reaction run in TFE as a solvent did not result in any decarboxylation (Table 1, entry 10).

In addition to the requirement for water, it was determined that phosphine ligands were necessary (Table 1, entry 11), either as ligands or as participants in the reaction as discussed later. The typical catalyst used, $\mathrm{Pd}\left(\mathrm{PPh}_{3}\right)_{4}$, worked well, however, it was found that a more ideal ratio of palladium metal to ligand was $1: 1$ or $1: 2$, with greater amounts of triphenylphosphine lowering the reaction yield when using the $\mathrm{Pd}_{2} \mathrm{dba}_{3}$ catalyst (Table 1 , entries 12-14). It was determined that reactions performed in

Table 1: Optimization of the one-component decarboxylation reaction. ${ }^{\mathrm{a}}$

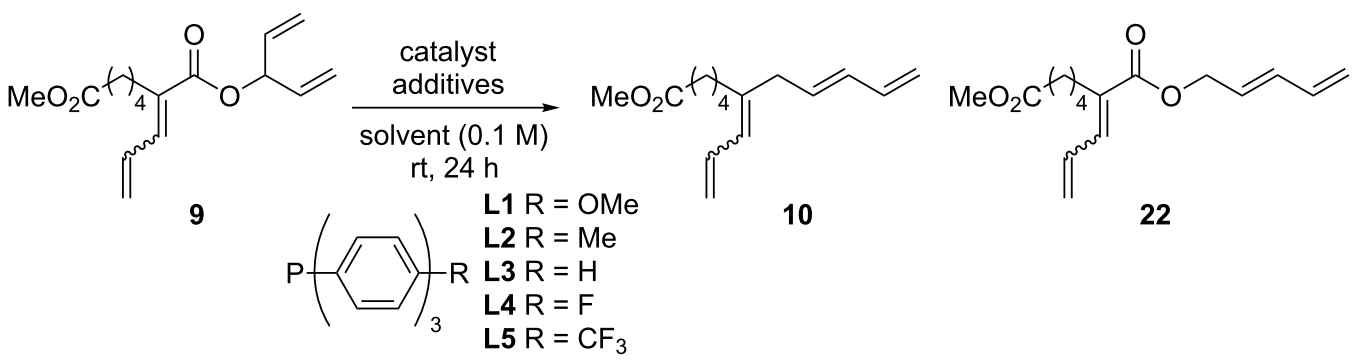

\begin{tabular}{|c|c|c|c|c|}
\hline Entry & Catalyst & Solvent & Additives & $\begin{array}{l}\text { Yield of } 10 \\
(\text { Yield of } 22)^{b}\end{array}$ \\
\hline 1 & $\mathrm{Pd}\left(\mathrm{PPh}_{3}\right)_{4}$ & $\mathrm{CH}_{2} \mathrm{Cl}_{2}$ & anhydrous & $0 \%(99 \%)$ \\
\hline 2 & $\mathrm{Pd}\left(\mathrm{PPh}_{3}\right)_{4}$ & $\mathrm{CH}_{2} \mathrm{Cl}_{2}$ & 0.5 equiv $\mathrm{H}_{2} \mathrm{O}$ & $27 \%$ \\
\hline 3 & $\mathrm{Pd}\left(\mathrm{PPh}_{3}\right)_{4}$ & $\mathrm{CH}_{2} \mathrm{Cl}_{2}$ & 1.1 equiv $\mathrm{H}_{2} \mathrm{O}$ & $77 \%$ \\
\hline 4 & $\mathrm{Pd}\left(\mathrm{PPh}_{3}\right)_{4}$ & $\mathrm{CH}_{2} \mathrm{Cl}_{2}$ & 1.3 equiv $\mathrm{H}_{2} \mathrm{O}$ & $72 \%$ \\
\hline 5 & $\mathrm{Pd}\left(\mathrm{PPh}_{3}\right)_{4}$ & $\mathrm{CH}_{2} \mathrm{Cl}_{2}$ & silylated glass, 1 equiv $\mathrm{H}_{2} \mathrm{O}$ & $55 \%(15 \%)$ \\
\hline 6 & $\mathrm{Pd}\left(\mathrm{PPh}_{3}\right)_{4}$ & $\mathrm{CH}_{2} \mathrm{Cl}_{2}$ & dry glass balls & $37 \%(24 \%)$ \\
\hline 7 & $\mathrm{Pd}\left(\mathrm{PPh}_{3}\right)_{4}$ & $\mathrm{CH}_{2} \mathrm{Cl}_{2}$ & wet glass balls & $51 \%$ \\
\hline 8 & $\mathrm{Pd}\left(\mathrm{PPh}_{3}\right)_{4}$ & $\mathrm{CH}_{2} \mathrm{Cl}_{2} / \mathrm{H}_{2} \mathrm{O}$ & biphasic & $49 \%$ \\
\hline 9 & $\mathrm{Pd}\left(\mathrm{PPh}_{3}\right)_{4}$ & $\mathrm{CH}_{2} \mathrm{Cl}_{2}$ & 1 equiv $\mathrm{MeOH}, 1$ equiv $\mathrm{H}_{2} \mathrm{O}$ & $33 \%(26 \%)$ \\
\hline 10 & $\mathrm{Pd}\left(\mathrm{PPh}_{3}\right)_{4}$ & TFE & trace $\mathrm{CH}_{2} \mathrm{Cl}_{2}$ & $0 \%$ \\
\hline 11 & $\mathrm{Pd}_{2}(\mathrm{dba})_{3}$ & $\mathrm{CH}_{2} \mathrm{Cl}_{2}$ & 0 mol $\% \mathrm{PPh}_{3}, 1$ equiv $\mathrm{H}_{2} \mathrm{O}$ & $0 \%$ \\
\hline 12 & $\mathrm{Pd}_{2}(\mathrm{dba})_{3}$ & $\mathrm{CH}_{2} \mathrm{Cl}_{2}$ & 10 mol \% $\mathrm{PPh}_{3}, 1$ equiv $\mathrm{H}_{2} \mathrm{O}$ & $64 \%$ \\
\hline 13 & $\mathrm{Pd}_{2}(\mathrm{dba})_{3}$ & $\mathrm{CH}_{2} \mathrm{Cl}_{2}$ & $20 \mathrm{~mol} \% \mathrm{PPh}_{3}, 1$ equiv $\mathrm{H}_{2} \mathrm{O}$ & $61 \%$ \\
\hline 14 & $\mathrm{Pd}_{2}(\mathrm{dba})_{3}$ & $\mathrm{CH}_{2} \mathrm{Cl}_{2}$ & 30 mol \% $\mathrm{PPh}_{3}, 1$ equiv $\mathrm{H}_{2} \mathrm{O}$ & $12 \%$ \\
\hline 15 & $\mathrm{Pd}_{2}(\mathrm{dba})_{3}$ & $\mathrm{CH}_{2} \mathrm{Cl}_{2}$ & 10 mol $\%$ L1, 1 equiv $\mathrm{H}_{2} \mathrm{O}$ & $70 \%$ \\
\hline 16 & $\mathrm{Pd}_{2}(\mathrm{dba})_{3}$ & $\mathrm{CH}_{2} \mathrm{Cl}_{2}$ & 10 mol \% L2, 1 equiv $\mathrm{H}_{2} \mathrm{O}$ & $70 \%$ \\
\hline 17 & $\mathrm{Pd}_{2}(\mathrm{dba})_{3}$ & $\mathrm{CH}_{2} \mathrm{Cl}_{2}$ & 10 mol \% L4, 1 equiv $\mathrm{H}_{2} \mathrm{O}$ & $18 \%$ \\
\hline 18 & $\mathrm{Pd}_{2}(\mathrm{dba})_{3}$ & $\mathrm{CH}_{2} \mathrm{Cl}_{2}$ & 10 mol $\%$ L5, 1 equiv $\mathrm{H}_{2} \mathrm{O}$ & $10 \%$ \\
\hline 19 & $\mathrm{Pd}(\mathrm{OAc})_{2}$ & $\mathrm{CH}_{2} \mathrm{Cl}_{2}$ & 1 equiv $\mathrm{H}_{2} \mathrm{O}$ & $0 \%$ \\
\hline 20 & $\mathrm{Pd}(\mathrm{OAc})_{2}$ & $\mathrm{CH}_{2} \mathrm{Cl}_{2}$ & 40 mol $\% \mathrm{PPh}_{3}, 1$ equiv $\mathrm{H}_{2} \mathrm{O}$ & $10 \%$ \\
\hline 21 & none & $\mathrm{CH}_{2} \mathrm{Cl}_{2}$ & 1 equiv $\mathrm{PPh}_{3}, 1$ equiv $\mathrm{H}_{2} \mathrm{O}$ & $0 \%$ \\
\hline
\end{tabular}

${ }^{a}$ Reaction Conditions: Pd metal (10 mol \%) and the indicated solvent and additives for 24 hours. ${ }^{b}$ Isolated yields. 
the presence of electron-rich ligands had both quicker kinetics and more efficient yields compared to electron-deficient ligands (Table 1, entries 15-18 and Supporting Information File 1 for kinetic information). Although not as efficient, it was found that a palladium(II) catalyst functioned in this reaction, presumably functioning as a pre-catalyst and being reduced in situ to the palladium(0) catalyst (Table 1, entries 19 and 20). As a control reaction, it was found that no reaction occurred in the absence of palladium catalyst (Table 1, entry 21 ).

As shown earlier, bis-allylic sorbate $\mathbf{1 3}$ (Scheme 2) was found to be low yielding for the decarboxylative coupling reaction. Reactions of sorbate $\mathbf{1 3}$ monitored by ${ }^{1} \mathrm{H}$ NMR showed nearly quantitative isomerization of the bis-allylic group into a linear pentadienyl system. Increasing the reaction time did not result in greater conversion to tetraene $\mathbf{8 a}$, which indicates that the products may be competitively ligating and poisoning the $\operatorname{Pd}(0)$ catalyst (see Supporting Information File 1 for additional evidence of product inhibition). The isomerization reaction to form 22 was presumably occurring via ionization of the allylic system using $\operatorname{Pd}(0)$, followed by recombination of the carboxylate at the terminal position of the pentadienyl system. Based on these data, we hypothesized that a two-component reaction using a dienoic acid and bis-allylic acetate might be possible, however, the presence of both water and a carboxylic acid would increase the possibility for isomerization of the 1,3,6,8tetraenes into the fully conjugated 1,3,5,7-tetraenes, or possibly polymerization.
Despite the low yield for decarboxylation with sorbate 13, the initial attempt used inexpensive sorbic acid as the dienoic acid. Gratifyingly, this reaction was successful and it was again determined that no isomerization to the fully conjugated system was observed (Table 2, entry 1). Other bis-allylic leaving groups were studied and, unexpectedly, it was determined that divinylcarbinol was superior (Table 2, entries 1-6). In fact, the better leaving groups were either slow or ineffective. This could be due to the less basic leaving groups not sufficiently deprotonating sorbic acid, which may be required for this reaction as is discussed mechanistically later (Scheme 3). Similar to the single component reaction, more than two equivalents of phosphine, relative to palladium metal, was detrimental (compare entries $12-14$ of Table 1 with entries 6-8 of Table 2), however, the reaction was successful using $\mathrm{Pd}\left(\mathrm{PPh}_{3}\right)_{4}$ (Table 1, entry 9).

To further understand this interesting decarboxylative coupling reaction, a handful of different pentadienyl electrophiles and dienoic acids were examined (Table 3 ). Typically, the pentadienyl alcohol was used; however, in some cases the acetate was superior. It was found that both a methyl or phenyl substituent on the alcohol derivative would result in branched product $\mathbf{8 b}$ or 8d as a major product with a product ratio of $6: 1$ or $4: 1$, respectively (Table 3, entries 2-4). The yields for these reactions were low, but the remaining material was typically starting material and the ester where the acid and alcohol are coupled together. There was no effect on the yields upon leaving the reactions longer than 48 hours and it was found that the addition of

Table 2: Optimization of the two-component decarboxylation reaction. ${ }^{\mathrm{a}}$

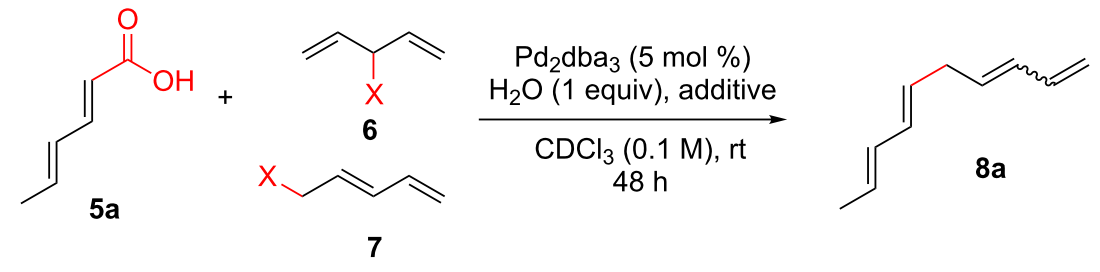

\begin{tabular}{|c|c|c|c|}
\hline Entry & Pentadienyl group & Additive & Yield $^{\mathrm{b}}$ \\
\hline 1 & $6 \mathbf{a}, X=O A c$ & $\mathrm{PPh}_{3}(20 \mathrm{~mol} \%)$ & $12 \%$ \\
\hline 2 & $6 b, X=\mathrm{OCO}_{2} \mathrm{Me}$ & $\mathrm{PPh}_{3}(20 \mathrm{~mol} \%)$ & $35 \%$ \\
\hline 3 & 6c, $X=O B z$ & $\mathrm{PPh}_{3}(20 \mathrm{~mol} \%)$ & $11 \%$ \\
\hline 4 & $\mathbf{6 d}, \mathrm{X}=\mathrm{O}_{2} \mathrm{C}\left(4-\mathrm{CF}_{3} \mathrm{Ph}\right)$ & $\mathrm{PPh}_{3}(20 \mathrm{~mol} \%)$ & $6 \%$ \\
\hline 5 & $7 \mathrm{a}, \mathrm{X}=\mathrm{Br}$ & $\mathrm{PPh}_{3}(20 \mathrm{~mol} \%)$ & $0 \%$ \\
\hline 6 & $6 e, X=O H$ & $\mathrm{PPh}_{3}(20 \mathrm{~mol} \%)$ & $40 \%$ \\
\hline 7 & $6 e, X=O H$ & $\mathrm{PPh}_{3}(10 \mathrm{~mol} \%)$ & $18 \%$ \\
\hline 8 & $6 e, X=O H$ & $\mathrm{PPh}_{3}(30 \mathrm{~mol} \%)$ & $24 \%$ \\
\hline $9^{c}$ & $6 \mathbf{e}, \mathrm{X}=\mathrm{OH}$ & NA & $28 \%$ \\
\hline
\end{tabular}

aReaction conditions: Sorbic acid (5a, 1 equiv), pentadienyl group ( 6 or 7,1 equiv), $\mathrm{Pd}_{2}\left(\mathrm{dba}_{3} \cdot \mathrm{CHCl}_{3}\left(5\right.\right.$ mol \%) unless indicated otherwise, $\mathrm{H}_{2} \mathrm{O}$ (1 equiv), in $\mathrm{CDCl}_{3}$ for 48 hours. ${ }^{b} \mathrm{NMR}$ yields. ${ }^{\mathrm{P}} \mathrm{Pd}\left(\mathrm{PPh}_{3}\right)_{4}(10 \mathrm{~mol} \%)$. 
Table 3: Substrate scope for the two-component decarboxylation reaction. ${ }^{a}$
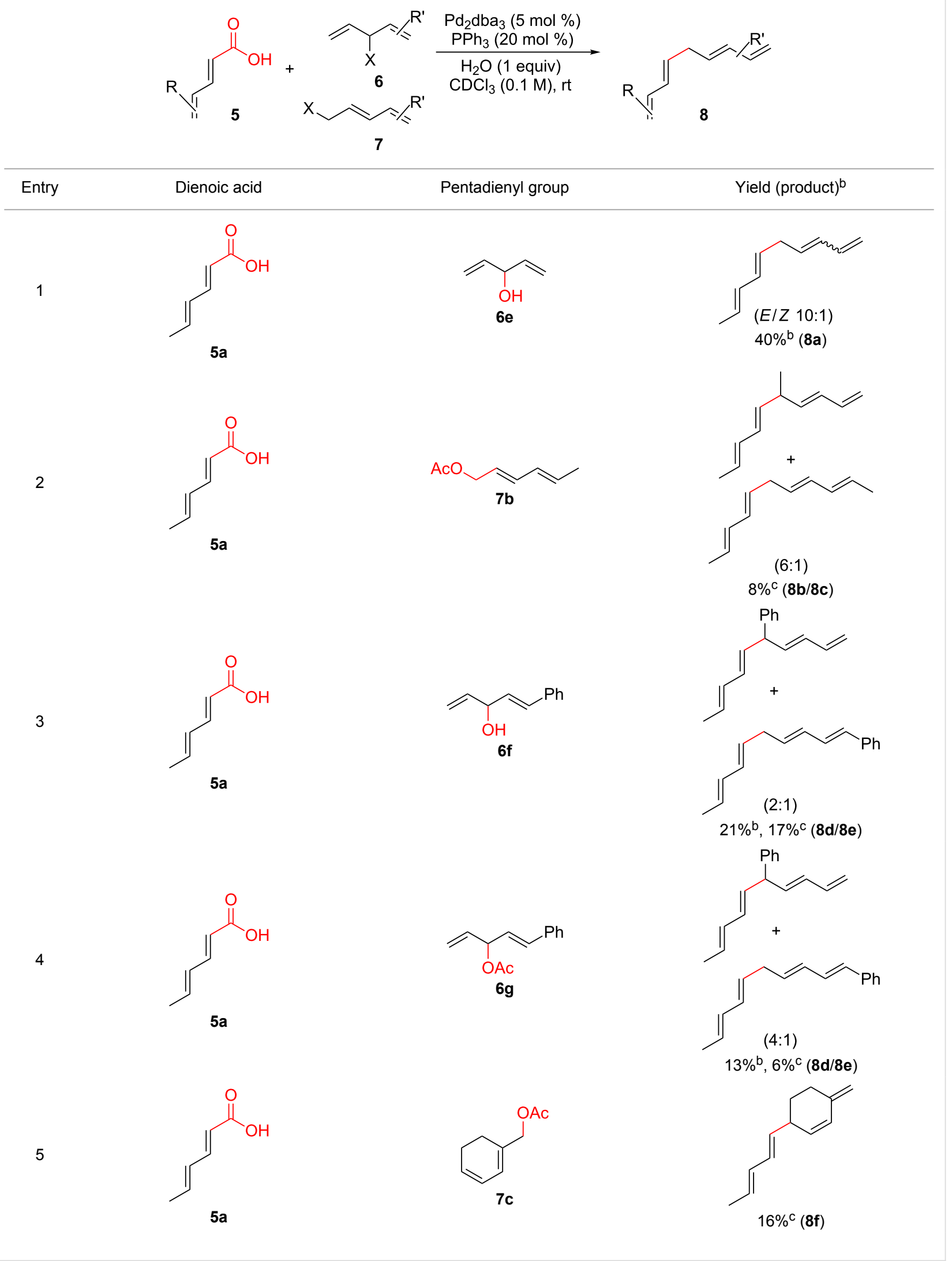
Table 3: Substrate scope for the two-component decarboxylation reaction. ${ }^{\text {a }}$ (continued)

6<smiles>C/C=C/C=C/C(=O)O</smiles>

$5 a$<smiles>C=C/C=C/C(=O)O</smiles>

$5 b$

8<smiles>O=C(O)/C=C/C=C/c1ccccc1</smiles>

$5 c$

9<smiles>C=C(C)/C=C/C(=O)O</smiles>

$5 d$

10<smiles>Cc1ccc(C(=[18O])/C=C/C(=O)O)cc1</smiles>

11<smiles>O=C(O)C1=CC=CCC1</smiles>

$5 f$

12<smiles>C=CC1=C(C(=O)O)CCC1</smiles>

$5 \mathrm{~g}$<smiles>C=CC1=C(COC(C)=O)CCC1</smiles><smiles>C=CC(O)C=C</smiles><smiles>C=CC(O)C=C</smiles><smiles>C=CC(O)C=C</smiles>

$6 e$<smiles>C=CC(O)C=C</smiles><smiles>C=CC(O)C=C</smiles>

$6 e$<smiles>C=CC(O)C=C</smiles>

$6 e$
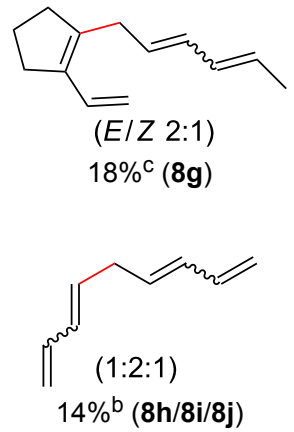<smiles>C=C/C=C/C/C=C/C=C/c1ccccc1</smiles>

$24 \%^{\mathrm{c}}(8 \mathrm{k})$<smiles>C=CC=CCC=CC(=C)C</smiles>

$36 \%^{\mathrm{b}}(\mathbf{8 I})$

decomposition

decomposition

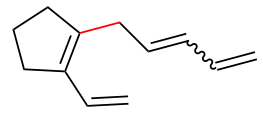

(E/Z 2:1)

$74 \%^{\mathrm{C}}(8 \mathrm{~m})$

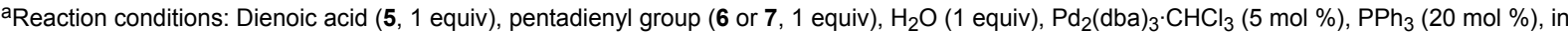
$\mathrm{CDCl}_{3}$ for $48 \mathrm{~h}$. b NMR yields due to volatility of product. CIsolated yields.

tetraene product inhibited the reaction (see Supporting Information File 1 for details). With these highly unsubstituted tetraene products, it is hypothesized that the product may be sequestering the palladium catalyst. Two cyclic dienyl acetates were also studied (Table 3, entries 5 and 6) and they yielded tetraenes $\mathbf{8 f}$ and $\mathbf{8 g}$. The dienes of entries 5 and 6 could have formed additional isomers by coupling to the other end of the pentadienyl group, but only one regioisomer was observed.
With respect to the dienoic acid, it was determined that the unsubstituted compound, pentadienoic acid, underwent decarboxylative coupling, although as a mixture of $E / E, E / Z$, and $Z / Z$ isomers (Table 3, entry 7). Alkyl and aryl substituents were possible on the dienoate with the exception of an aryl group at the gamma position (Table 3, entries 8-10). Two cyclic dienoic acids were synthesized [56,57] and while the cyclohexadienoic acid did not decarboxylate (Table 3 , entry 11), the vinylcy- 
clopentenoic acid had a good yield of a complex tetraene (Table 3, entry 12).

Based on the information obtained during optimization and screening of compounds, two potential mechanisms are proposed (Scheme 3). Both options allow for the one (13) or two (5 and 6) component process to be used while also allowing for the reversible formation of linear ester 23. Pathway B involves a Morita-Baylis-Hillman type process. The role of water would be to hydrogen bond to the carboxylate to make the system more electrophilic (B). This would accelerate the addition of the phosphine to generate zwitterion C [58]. Preliminary modeling for this ion indicates that both the electrophilic terminal vinyl group of the pentadienyl ligand and the nucleophilic $\alpha$-carbon are in close proximity to one another. Formation of the carbon-carbon bond would then regenerate the $\operatorname{Pd}(0)$ catalyst and phosphonium carboxylate $\mathbf{D}$. Decarboxylative elimination of the phosphine results in formation the 1,3,6,8-tetraene. It is proposed for pathway B that the dienoate is required so that the $\alpha$-carbon is not blocked by the bulky phosphine group since it can add in a 1,6- or 1,4-manner, both reversibly.

Alternatively, pathway A has the palladium catalyst coordinate to one of the alkenes of the dienoate instead of the carboxylate (E). It is proposed that a water cluster around the carboxylate would enable this process by hydrogen bonding to the carboxylate. The conversion of $\mathbf{E}$ to $\mathbf{F}$ would form the $\mathrm{C}-\mathrm{C}$ bond by having the palladium catalyst convert from one type of $\eta^{3}$-allyl

and $\pi$-complex (E) to a different allyl $/ \pi$-complex (F). Finally, decarboxylative reduction of the palladium would release the product while regenerating the catalyst. Preliminary computational calculations using NEB [59] support pathway A and the HOMO of the transition state between $\mathbf{E}$ and $\mathbf{F}$ (Figure 1) calculated using the Gaussian 09 implementation of DFT with a B3LYP functional, 6-31g* basis, and polarized continuum model of solvation for DCM, shows close proximity of two in-phase orbitals for the requisite $\mathrm{C}-\mathrm{C}$ bond, whereas removal

(1)

E

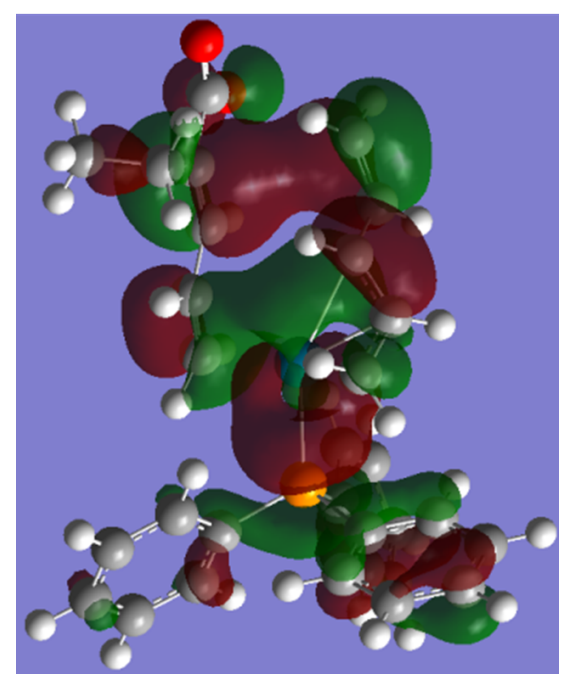

Figure 1: Calculated HOMO of transition state between $\mathbf{E}$ and $\mathbf{F}$.

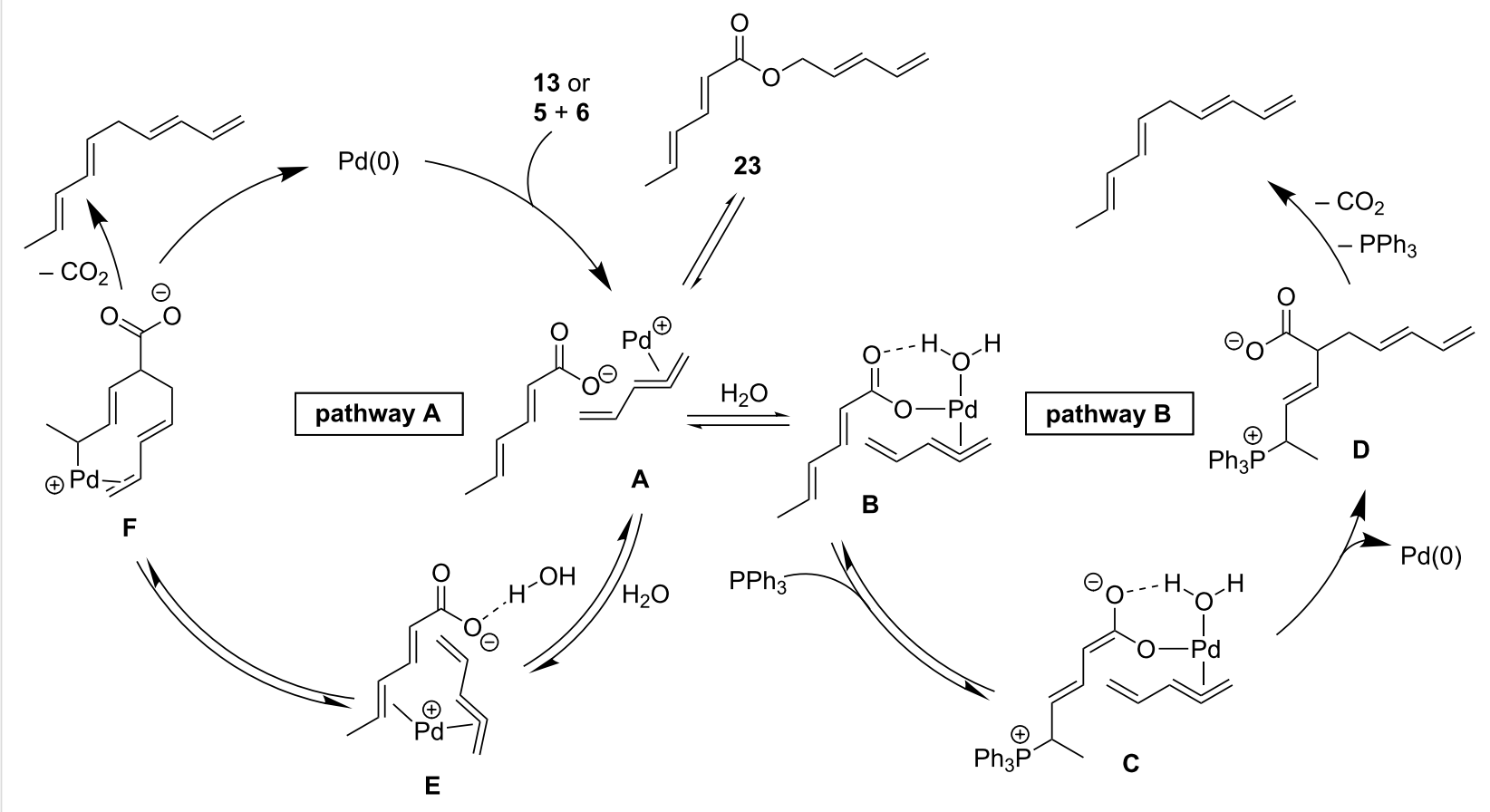


of any one of the alkenes from this structure would lead to antibonding relationships to bond to the alpha carbon.

\section{Conclusion}

In summary, we present information that is of value to advancing the area of metal-catalyzed decarboxylative coupling reactions, specifically those of pentadienyl dienoates that do not require an anion-stabilizing group, are run at ambient temperature, and can utilize the more accessible alcohol for a leaving group. This reaction was advanced to be possible in a two-component fashion, allowing for the conversion of dienoic acids and pentadienyl alcohols into 1,3,6,8-tetraenes with the only stoichiometric byproducts being water and carbon dioxide. These reactions currently require a diene motif with each coupling partner, but the product maintains the independent reactivity opportunities of these isolated dienes as opposed to forming the fully conjugated 1,3,5,7-tetraene. A variety of substrates were explored where each of the unique positions on the coupling partners was modified and two different mechanistic pathways are presented. A more in-depth mechanistic analysis to improve the yields and to explore other reactivity possibilities based on this process are currently being studied and will be published in due time.

\section{Supporting Information}

\section{Supporting Information File 1}

Experimental procedures and analytical data for all substrates and products, product inhibition study, computational calculation information, and relevant energies and Cartesian coordinates.

[http://www.beilstein-journals.org/bjoc/content/ supplementary/1860-5397-13-41-S1.pdf]

\section{Acknowledgements}

Funding for this project from the North Carolina Biotechnology Center (BRG-1205) and University of North Carolina at Greensboro is gratefully acknowledged. The authors thank Dr. Franklin J. Moy for assisting with analysis of NMR data and Dr. Daniel A. Todd for acquisition of the high resolution mass spectrometry data at the Triad Mass Spectrometry Laboratory at the University of North Carolina at Greensboro.

\section{References}

1. Torborg, C.; Beller, M. Adv. Synth. Catal. 2009, 351, 3027. doi:10.1002/adsc.200900587

2. McGlacken, G. P.; Fairlamb, I. J. S. Eur. J. Org. Chem. 2009, 4011. doi:10.1002/ejoc.200900139

3. Nicolaou, K. C.; Bulger, P. G.; Sarlah, D. Angew. Chem., Int. Ed. 2005, 44, 4442. doi:10.1002/anie.200500368
4. Terao, J.; Kambe, N. Acc. Chem. Res. 2008, 41, 1545. doi:10.1021/ar800138a

5. Martin, R.; Buchwald, S. L. Acc. Chem. Res. 2008, 41, 1461. doi:10.1021/ar800036s

6. Marion, N.; Nolan, S. P. Acc. Chem. Res. 2008, 41, 1440. doi:10.1021/ar800020y

7. Denmark, S. E.; Regens, C. S. Acc. Chem. Res. 2008, 41, 1486. doi:10.1021/ar800037p

8. Kantchev, E. A. B.; O'Brien, C. J.; Organ, M. G. Angew. Chem., Int. Ed. 2007, 46, 2768. doi:10.1002/anie.200601663

9. Corbet, J.-P.; Mignani, G. Chem. Rev. 2006, 106, 2651. doi:10.1021/cr0505268

10. Schaub, T. A.; Kivala, M. Cross-Coupling Reactions to sp Carbon Atoms. Metal-Catalyzed Cross-Coupling Reactions and More; Wiley-VCH Verlag GmbH \& Co. KGaA: Weinheim, 2014; pp 665 ff.

11. Davies, H. M. L.; Morton, D. J. Org. Chem. 2016, 81, 343. doi:10.1021/acs.joc.5b02818

12. Brückl, T.; Baxter, R. D.; Ishihara, Y.; Baran, P. S. Acc. Chem. Res. 2012, 45, 826. doi:10.1021/ar200194b

13. Stuart, D. R.; Fagnou, K. The Discovery and Development of a Palladium(II)-Catalyzed Oxidative Cross-Coupling of Two Unactivated Arenes. In Inventing Reactions; Gooßen, L. J., Ed.; Springer: Berlin, Heidelberg, 2013; pp $91 \mathrm{ff}$.

14. Colby, D. A.; Bergman, R. G.; Ellman, J. A. Chem. Rev. 2010, 110, 624. doi:10.1021/cr900005n

15. Campeau, L.-C.; Rousseaux, S.; Fagnou, K. J. Am. Chem. Soc. 2005, 127, 18020. doi:10.1021/ja056800x

16. Stuart, D. R.; Alsabeh, P.; Kuhn, M.; Fagnou, K. J. Am. Chem. Soc. 2010, 132, 18326. doi:10.1021/ja1082624

17. Gorelsky, S. I.; Lapointe, D.; Fagnou, K. J. Org. Chem. 2012, 77, 658. doi:10.1021/jo202342q

18. Lafrance, M.; Fagnou, K. J. Am. Chem. Soc. 2006, 128, 16496. doi:10.1021/ja067144j

19. Jana, R.; Trivedi, R.; Tunge, J. A. Org. Lett. 2009, 11, 3434 doi:10.1021/ol901288r

20. Tokoroyama, T.; Nakamura, M. Chem. Lett. 1977, 6, 659. doi:10.1246/cl.1977.659

21. Tsuda, T.; Chujo, Y.; Nishi, S.; Tawara, K.; Saegusa, T. J. Am. Chem. Soc. 1980, 102, 6381. doi:10.1021/ja00540a053

22. Tsuda, T.; Okada, M.; Nishi, S.; Saegusa, T. J. Org. Chem. 1986, 51, 421. doi:10.1021/jo00354a001

23. Trost, B. M.; Bunt, R. C. J. Am. Chem. Soc. 1998, 120, 70. doi:10.1021/ja9726522

24. Corey, E. J.; Fraenkel, G. J. Am. Chem. Soc. 1953, 75, 1168. doi:10.1021/ja01101a047

25. Waetzig, S. R.; Rayabarapu, D. K.; Weaver, J. D.; Tunge, J. A. Angew. Chem., Int. Ed. 2006, 45, 4977. doi:10.1002/anie.200600721

26. Waetzig, S. R.; Tunge, J. A. J. Am. Chem. Soc. 2007, 129, 14860. doi:10.1021/ja077070r

27. Grenning, A. J.; Tunge, J. A. Org. Lett. 2010, 12, 740. doi:10.1021/ol902828p

28. Rayabarapu, D. K.; Tunge, J. A. J. Am. Chem. Soc. 2005, 127, 13510. doi:10.1021/ja0542688

29. Sim, S. H.; Park, H.-J.; Lee, S. I.; Chung, Y. K. Org. Lett. 2008, 10, 433. doi:10.1021/ol702577g

30. Pi, S.-F.; Tang, B.-X.; Li, J.-H.; Liu, Y.-L.; Liang, Y. Org. Lett. 2009, 11, 2309. doi:10.1021/ol900643r

31. Torregrosa, R. R. P.; Ariyarathna, Y.; Chattopadhyay, K.; Tunge, J. A. J. Am. Chem. Soc. 2010, 132, 9280. doi:10.1021/ja1035557 
32. Zhang, W.-W.; Zhang, X.-G.; Li, J.-H. J. Org. Chem. 2010, 75, 5259. doi:10.1021/jo1010284

33. Rodriguez, N.; Goossen, L. J. Chem. Soc. Rev. 2011, 40, 5030. doi:10.1039/c1cs15093f

34. Gooßen, L. J.; Deng, G.; Levy, L. M. Science 2006, 313, 662. doi:10.1126/science.1128684

35. Gruber, S.; Zaitsev, A. B.; Wörle, M.; Pregosin, P. S.; Veiros, L. F. Organometallics 2008, 27, 3796. doi:10.1021/om800295z

36. Yamashita, M.; Hirano, K.; Satoh, T.; Miura, M. Org. Lett. 2010, 12, 592. doi:10.1021/ol9027896

37. Patel, B. A.; Dickerson, J. E.; Heck, R. F. J. Org. Chem. 1978, 43, 5018. doi:10.1021/jo00420a029

38. Yamashita, M.; Hirano, K.; Satoh, T.; Miura, M. Adv. Synth. Catal. 2011, 353, 631. doi:10.1002/adsc.201000897

39. Yamashita, M.; Hirano, K.; Satoh, T.; Miura, M. Chem. Lett. 2010, 39, 68. doi:10.1246/cl.2010.68

40. Abu Deiab, G. I.; Croatt, M. P. Chapter 3 - Step-Economical Synthesis of Clinprost and Analogs Utilizing a Novel Decarboxylation Reaction. In Strategies and Tactics in Organic Synthesis; Michael, H., Ed.; Academic Press, 2017; Vol. 12, pp $95 \mathrm{ff}$.

41. Nagy, E. E.; Hyatt, I. F. D.; Gettys, K. E.; Yeazell, S. T.; Frempong, S. K., Jr.; Croatt, M. P. Org. Lett. 2013, 15, 586. doi:10.1021/ol303402e

42. Thadani, A. N.; Rawal, V. H. Org. Lett. 2002, 4, 4317. doi:10.1021/ol0269594

43. Wilson, S. R.; Zucker, P. A. J. Org. Chem. 1988, 53, 4682. doi:10.1021/jo00255a007

44. Tang, W.; Prusov, E. V. Org. Lett. 2012, 14, 4690. doi:10.1021/ol302219x

45. Gagnepain, J.; Moulin, E.; Fürstner, A. Chem. - Eur. J. 2011, 17, 6964. doi:10.1002/chem.201100178

46. Jeso, V.; Micalizio, G. C. J. Am. Chem. Soc. 2010, 132, 11422. doi:10.1021/ja104782u

47. Schnermann, M. J.; Romero, F. A.; Hwang, I.; Nakamaru-Ogiso, E.; Yagi, T.; Boger, D. L. J. Am. Chem. Soc. 2006, 128, 11799. doi:10.1021/ja0632862

48. McCammant, M. S.; Shigeta, T.; Sigman, M. S. Org. Lett. 2016, 18, 1792. doi:10.1021/acs.orglett.6b00517

49. Todd, D. P.; Thompson, B. B.; Nett, A. J.; Montgomery, J. J. Am. Chem. Soc. 2015, 137, 12788. doi:10.1021/jacs.5b08448

50. Kong, W.; Che, C.; Kong, L.; Zhu, G. Tetrahedron Lett. 2015, 56, 2780. doi:10.1016/j.tetlet.2015.04.036

51. Xu, S.; Zhu, S.; Shang, J.; Zhang, J.; Tang, Y.; Dou, J. J. Org. Chem. 2014, 79, 3696. doi:10.1021/jo500375q

52. Huang, Y.; Fañanás-Mastral, M.; Minnaard, A. J.; Feringa, B. L. Chem. Commun. 2013, 49, 3309. doi:10.1039/c3cc41021h

53. Schmidt, A.; Hilt, G. Org. Lett. 2013, 15, 2708. doi:10.1021/ol401015e

54. Lim, H. N.; Parker, K. A. J. Am. Chem. Soc. 2011, 133, 20149. doi:10.1021/ja209459f

55. Kennard, O.; Watson, D. G.; Fawcett, J. K.; Kerr, K. A. Tetrahedron 1970, 26, 607. doi:10.1016/S0040-4020(01)97853-6

56. Hettrick, C. M.; Kling, J. K.; Scott, W. J. J. Org. Chem. 1991, 56, 1489. doi:10.1021/jo00004a028

57. Gradén, H.; Hallberg, J.; Kann, N.; Olsson, T. J. Comb. Chem. 2004, 6, 783. doi:10.1021/cc049929w

58. Surovtseva, D. A.; Orlov, D. A.; Morozova, T. A.; Krylov, A. V.; Belov, A. P. Kinet. Catal. 2006, 47, 855.

doi:10.1134/s0023158406060073

59. Alfonso, D. R.; Jordan, K. D. J. Comput. Chem. 2003, 24, 990. doi:10.1002/jcc. 10233

\section{License and Terms}

This is an Open Access article under the terms of the Creative Commons Attribution License

(http://creativecommons.org/licenses/by/4.0), which permits unrestricted use, distribution, and reproduction in any medium, provided the original work is properly cited.

The license is subject to the Beilstein Journal of Organic Chemistry terms and conditions:

(http://www.beilstein-journals.org/bjoc)

The definitive version of this article is the electronic one which can be found at:

doi:10.3762/bjoc. 13.41 